\section{Hepatitis $B$ revaccination of neonates with inadequate response after primovaccination}

Passive-active immunization with hepatitis B immunoglobulin and hepatitis B vaccine has proved to be highly effective in preventing perinatal transmission of hepatitis $B$ infection ${ }^{1,2}$. An anti-HBs antibody level $>10 \mathrm{IU}^{-1}$ is considered to provide protection against hepatitis B infection ${ }^{3}$. Response to the vaccine depends on host factors like age, HLA type ${ }^{4}$ and the presence of diseases affecting immunity ${ }^{5,6}$. The immune response (expressed in $\left.I \mathrm{U}^{-1}\right)$ is higher in neonates than in adults? ${ }^{7}$. Even so, inadequate responses to hepatitis $B$ vaccine do occur. In adults additional vaccination in nonand low-responders has been reported to yield responses of $27-100 \%{ }^{8-10}$. The question of how to manage non-responders also arises for young children. As far as we know no data are available on additional vaccination in infants. Therefore, we report the results of revaccination offered to nine healthy neonates who developed $<10 \mathrm{IU}^{-1}$ anti-HBs after primovaccination and a booster dose.

Over the past 9 years, 705 healthy newborns from HBsAg positive mothers received HBIg (120-300 IU, CLB, Amsterdam, The Netherlands) at birth and were vaccinated within the first year with plasma or recombinant DNA vaccine according to several schemes including at least two initial doses and a booster dose.

Vaccine was always stored at $4^{\circ} \mathrm{C}$ and physicians. $\mathrm{HBsAg}$ and anti-HBs were measured (Ausria II, Ausab, Abbott Laboratories) 1 month after completion of the immunization schedule. Nine infants with a negative test for $\mathrm{HBsAg}$ and an anti-HBs level below $10 \mathrm{IU}^{-1}$ received three to four additional doses of plasma-derived $(10 \mu \mathrm{g})$ or recombinant DNA $(20 \mu \mathrm{g})$ vaccine in their second year of life.

After revaccination all infants showed an anti-HBs response $>10 \mathrm{IU}^{-1}$; seven children $(78 \%)$ developed $>50 \mathrm{IU} 1^{-1}$ anti-HBs and four of them $>100 \mathrm{IU}^{-1}$. The three non-responders after primovaccination (anti-HBs $0 \mathrm{IU} \mathrm{I}^{-1}$ ) had a response in the lower range (Figure 1 ). No hepatitis B infections were observed among these nine children during followup (median 51, range 33-92 months). Twelve months after completion of revaccination eight of the nine infants $(89 \%)$ still had $>10$ IU I $^{-1}$ anti-HBs. given into the quadriceps muscle by
Our data show that additional vaccination of infants who had a nondetectable or a weak response after primovaccination and no signs of hepatitis $B$ infection can yield responses with a high likelihood of protection against hepatitis B infection. From an epidemiological viewpoint this result is important since many of these children remain at risk for hepatitis B infection for years due to family contacts.

\section{R. del Canho*, S.W. Schalm* and R.A. Heijtink ${ }^{\dagger}$}

* Department of Internal Medicine II, University Hospital Dijkzigt, Rotterdam, The Netherlands.

${ }^{\dagger}$ Department of Virology, Erasmus University, Rotterdam, The Netherlands

\section{References}

1 Beasley, R.P., Hwang, L.Y., Lee, G.C., Lan, C. Foan, $C$. and Huang, F. Prevention of perinatally transmitted hepatitis $B$ virus infections with vaccine. Lancet 1983, II, 1099-1102

2 Stevens, C.E., Taylor, P.E., Tong. M.J., Toy, P.T. Vyas, G.N., Nair, P.V. ot al. Yeast-recombinant hepatitis B vaccine. Efficacy with hepatitis B immune globulin in prevention of perinatal hepatitis B virus transmission. JAMA 1987, 257 2612-2616

3 Szmuness, W., Stevens, C.E., Zang, E.A., Harley, E.J. and Kellner, A. A controlled clinical trial of the efficacy of the hepatitis B vaccine (Heptavax B): a final report. Hepatology 1981, 1, 377-385

4 Alper, C.A., Kruskall, M.S., Marcus-Bagley, D. Craven, D.E., Katz, A.J., Brink, S.J. et al. Genetic prediction of nonresponse to hepatitis $B$ vaccine. N. Engl. J. Med. 1989, 321, 708-712

5 Callis, L.M., Clanxet, J., Fortuny, G., Caballeria J., Carrasco, J.L. and Lardinois, R. Hepatitis B infection and vaccination in children undergoing hemodialysis. Acta Paediatr. Scand. 1985, 74, 213-218

6 Entacher, U., Jürgenssen, Q., Thun-Hohenstein, L., Simbruner, G., Khoss, A., Wank, H. et al. Hepatitis $B$ vaccination and immune response in children with malignant diseases. Eur. J. Pediatr. 1985, 144, 160-163

7 Jilg. W., Schmidt, M. and Deinhardt, F. Persistence of specific antibodies after hepatitis B vaccination. J. Hepatol. 1988, 6, 201-207

8 Hadler, S.C., Francis, D.P., Haynard, J.E., Thompson, S.E., Judson, F.N., Echenberg. D.F. et al. Long-term immunogenicity and efficacy of hepatitis $B$ vaccine in homosexual men. $N$. Engl. J. Med. 1986, 315, 209-214

9 Jilg, W., Schmidt, M. and Deinhardt, F. Immune response to hepatitis B revaccination. J. Med. Virol. 1988, 24, 377-384

10 Wismans, P., Hattum, J. van, Stelling, T., Poel, J., Gast, G.C. de. Effect of supplementary vaccination in healthy non-responders to hepatitis $B$ vaccination. Hepatogastroenterology 1988, 35, 78-79 hepatitis B immune globulin and hepatitis B

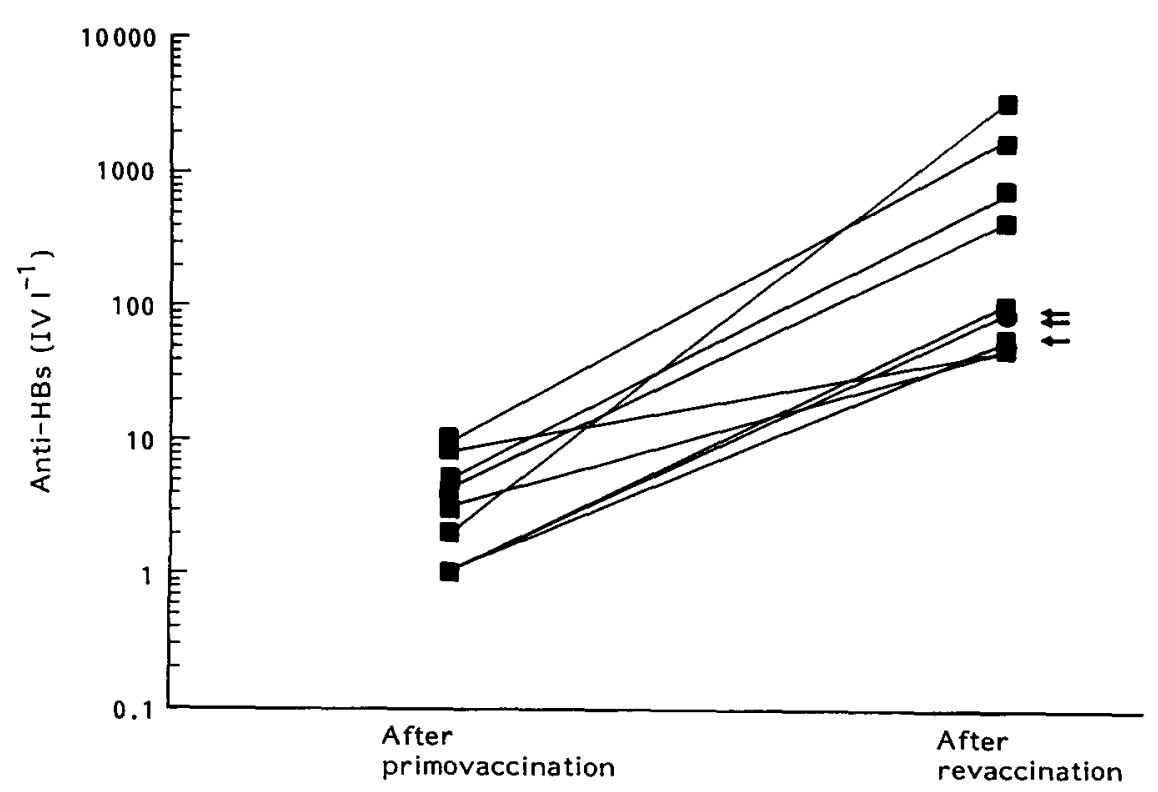

Figure 1 Anti-HBs response after hepatitis $B$ revaccination in intants, who were low-responder $(n=6)$ or non-responder $(n=3)$ after primovaccination and a booster dose. The non-responders are indicated by arrows 